\title{
We WAC Virtual Inter-Congress WAE Archaeology on the Global Stage
}

Kathryn Weedman Arthur, University of South Florida, St. Petersburg, USA

E-mail: kjarthur@usf.edu

John Carman, University of Birmingham, Birmingham, UK

E-mail: j.carman84@outlook.com

Published online: 17 August 2021

Dear WAC Members and Colleagues,

We invite you to listen, learn, discuss, and ask questions during our virtual WAC Inter-Congress. The Inter-Congress will be held online from August 30-September 3, 2021. The five planned sessions focus directly on the state of archaeological practice and practitioners today: Decoloniality, Black Lives Matter, Democracy, COVID-19, and Indigenous Narratives. For Session details, please refer to the Inter-Congress Preliminary Program at the end of this volume. Each session will consist of a keynote lecture followed by four papers and general discussion. Charles University is hosting the event and their Zoom-licence limits participation to 500 live connections. However, each session will be streamed on the You-Tube channel. Participation in the virtual WAC Inter-Congress is free of charge. Priority for participation will be given to WAC current members, but everyone is welcome. All you need to register can be found on the WAC website https://www.wac-9.org/.

Sincerely Jan Turek,

WAC-9 Academic Secretary

\section{In the News}

COVID is still with us. Its lessons are clear but horrifically unresolved. Structural racism penetrates our world. False allegations regarding innate vulnerability to the virus veil historical and present-day truths-that we live in an unjust world of our own making. This reality touches all our readers in our daily and academic lives.

UNESCO launched an online platform through which people can share how their cultural heritage and COVID-19 intersect in their lives (UNESCO 2021, Fig. 1). Many people commented how not being able to gather as a community and the cancellation of rituals and festivals during the pandemic has been painful, others point to the importance of their heritage knowledge in providing important food sources and medicinal 


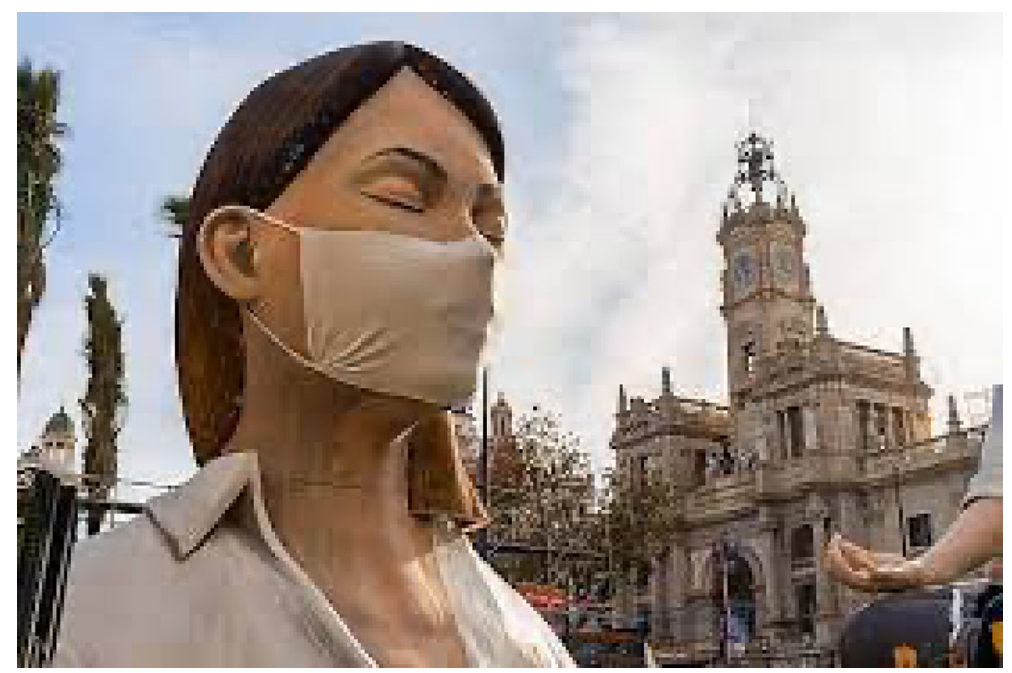

Figure 1. UNESCO: The celebration of Las Fallas Festival in Spain 2020 was postponed. Source: UNESCO 2021

healing in isolation. Still, others indicate how isolation has brought different generations together allowing for long time periods to share music, dance, and oral traditions that help relieve anxiety and help support resilience and recovery.

The importance of cultural heritage clearly expressed globally on the UNESCO platform demonstrates why WAC members reacted quickly to an offensive statement published in Expressions distributed on the WAC listserv. In the e-magazine's Discussion Forum (2020:5), the following statement was made: "Native Australians and Native Americans alike have lost most of their beliefs, their traditions, and their memory, and have acquired the beliefs, traditions, and memory of the colonizers. African tribes are now nations; they have suffered drastic colonization and have lost the tribal way of life" (Discussion Forum 2020:5). Prof. Paul Turnbull swiftly replied (WAC listserv March 9 reproduced with permission) "I Nearly Fell Off My Chair When I Read This in Your Free Issue" in response to this misrepresentation and ethnocentric statement published about Indigenous, First Nations, and Black histories. Expressions is a publication of UISPP's (2020) Commission on The Intellectual and Spiritual Expressions of Nonliterate Societies. WAC members followed with support for Turnbull's reaction through exasperated silence and expressions of outrage and disgust. Discussion ensued appealing for further actions ensuring that Indigenous people lead research projects, attain grant funding, and senior author publications with regard to their own histories. Peter Schmidt (March 18 


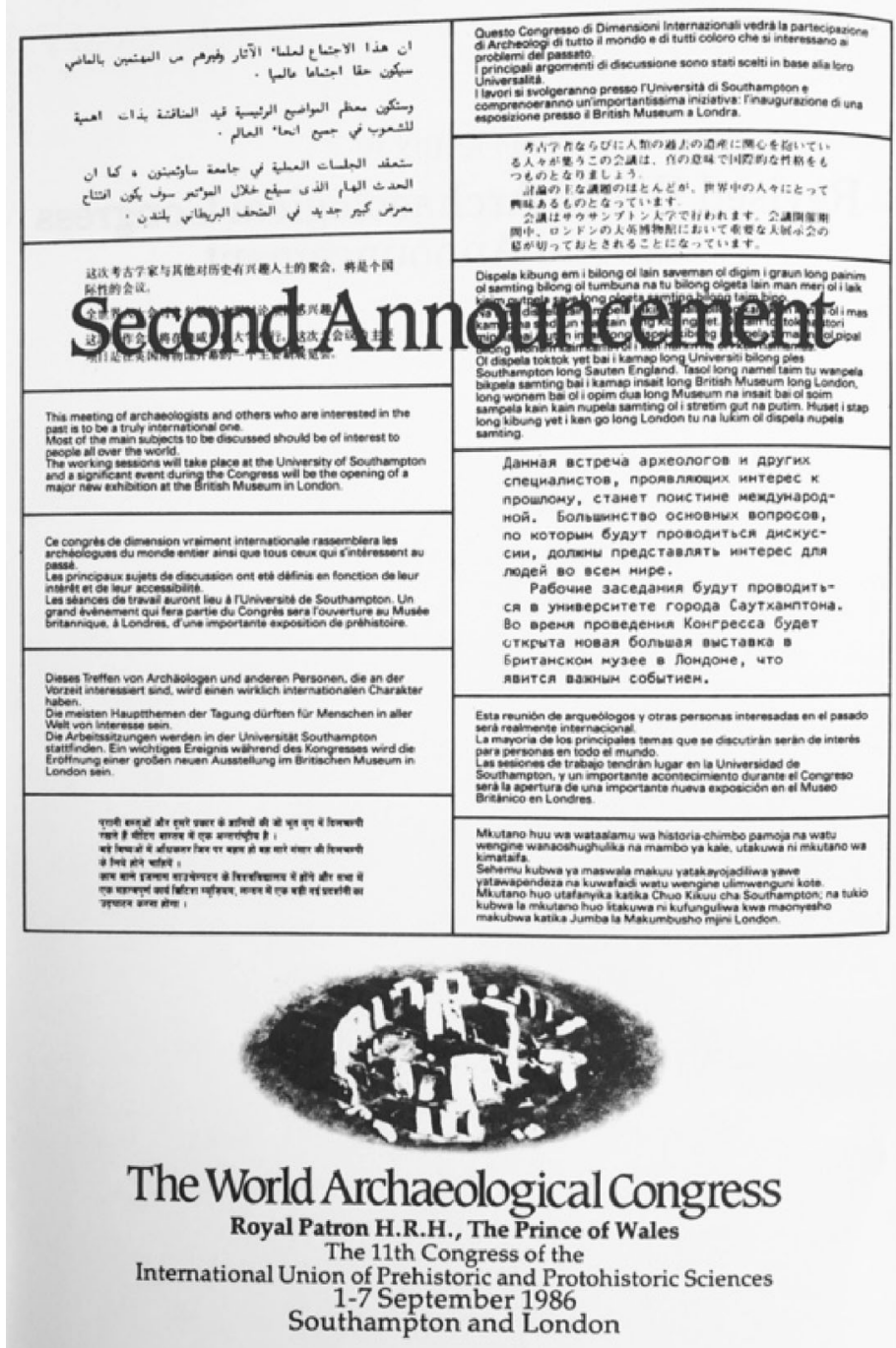

Figure 2. Second public announcement for First World Archaeological Congress (Ucko 1987, 258)

WAC listserv reproduced with permission) called for examining how WAC determines what is distributed on the listserv to avoid the circulation of uninformed and harmful ideas. Following this thread, it seems an opportune time to review WAC's history, reflect on our efforts to date, and perhaps adjust goals. 
As a start and a must read for all readers, Peter Ucko's (1987) detailed account of WAC's origins in his Academic Freedom \& Apartheid: The Story of the World Archaeological Congress. The agenda of the World Archaeological Congress' first meeting was to emphasize international participation beyond the global north, focus on global topics rather than geographical ones, avoid concurrent sessions, and pre-circulate papers and cassette record all the sessions to enhance the sharing of knowledge. The Congress announcement was circulated in 12 languages (Fig. 2) and 850 people from 71 countries participated.

On 20 March 2021, WAC listserv, Alice Kehoe reminded us of WAC's start and provided us with her brief history in the following narrative, reprinted here with her permission. "In fact, WAC began as a protest against exclusion of three Black archaeologists, from Namibia and Botswana. In 1986, in order to travel abroad, they had to obtain South African passports. Local organizers of the international archaeological congress to be held at Southampton, U.K., had obtained travel funds for them. At the time, the City of Southampton, protesting apartheid in South Africa, would not support any activity that included persons with South African passports. Peter Ucko, the local organizer of the congress, explained that the three were native to lands conquered and held as colonies by the Union of South Africa, and bringing them to participate as colleagues was strong protest against apartheid. No use. So, with many of us already in the city for the congress, we met on a sunny day at a pub with a large lawn and decided we would no longer participate in the more-than-a-centuryold congress that avoided politics, but organize a World Archaeological Congress that would work to bring First Nations archaeologists into international meetings. Our acronym WAC was laughed at, we're the WACky archaeologists working against imperial colonialism, YES!”.

In our hearts and minds. these issues continue to deeply affect us and challenge us to reassess the goals and identity of WAC and to work harder to address in our publications their realization.

\section{A Call for Submissions and Reviewers}

COVID has impacted the number of submissions to journals in all disciplines. Fewer scholars over the last year have submitted articles and agreed to complete reviews for Archaeologies. We hope that as we recover from the pandemic submissions will again increase. We call on the WAC Council, WAC members, and our readers to assist us in encouraging submissions to Archaeologies and to our reviewers and particularly Editorial Board members to undertake reviews in a timely manner when requested. 


\section{In This Issue}

We are very grateful to the authors who shared their research with us in this current issue. Their coverage of community and Indigenous heritage is global and reminds us that heritage is a living and on-going entity. Several articles in this issue stress the importance of heritage education to increase the number of Indigenous and national scholars and informed citizens. These efforts not only better preserve heritage resources, but also refocus control of historical narratives within communities. The critical need to refer to local historical and cultural sources as integral to archaeological methodologies is highlighted. Two other articles focus on incorporating local communities in state cultural tourism plans and how UNESCO tends to limit community value in defining and identifying sites of universal or global heritage value.

Nigerian archaeologist Kingsley Chinedu Daraojimba stresses the need for archaeology to be incorporated into Nigeria's primary and secondary education. He argues that archaeological curriculums will create informed citizens who will better understand the value of archaeological resources as a source for documenting and preserving their heritage. A heritage that has been deeply undermined by European control of historical narratives. Kingsley reveals his educational efforts in the Igbo-Ukwu region, which is rich in tangible and intangible cultural heritage. Read further to discover what he learned by creating a classroom education program at three secondary schools and a field training program for 11 residents, who live on the land of three important archaeological sites.

Polish archaeologist Anna Bogumila Kowalska demonstrates why it is import for our archaeological methodologies to incorporate local historical and cultural sources. She analyses leather footwear from eighth to fifteenth century southern Baltic sites in Wolin and Szczecin, Poland. Turn to her article in this issue, to discover what she learned about the hazards of focusing our methodologies only on analyzing the final products.

Li Tao and Qiaowei Wei are cultural heritage scholars in China, who present the re-discovery of the Longxing Buddhist temple, Qingzhou County, China. Subsequent to the excavations at the temple, there was an international museum exhibition and the site was designated as a "Key Cultural Heritage Site Under State-Level Protection". The authors discuss how state involvement led to cooperation between community officials, the local Buddhist community, archaeologists and historians to reconstruct the temple for tourism. In the process, the authors present several unexpected collaborative decisions about the new temple.

Hulya Yuceer and her colleagues specialize in archaeology, bioengineering, and architectural conservation and heritage tourism in Turkey. They 
discuss the conflicts that can arise over site value, management, and community involvement in the process of inclusion on UNESCO World Heritage list. They call for the addition on the list of Anazarbos, which was an important city in the Mediterranean since the Hellenistic period in the first century BC. Read further to discover the efforts they are making to forward local knowledge about Anazarbos to the world to encourage recognition of the site by UNESCO.

\section{References}

Forum, D.

(2021). Further debate on colonization. Expressions, 29, 5-6

Ucko, P.

(1987). Academic Freedom \& Apartheid: The Story of the World Archaeological Congress. Duckworth

UISPP.

(2020). The intellectual and spiritual expressions of non-literate societies commission quarterly magazine expressions. https://www.uispp.org/ intellectual-and-spiritual-expressions-non-literate-societies

UNESCO.

(2021). Living Heritage and The COVID-19 Pandemic: Snapshot of the UNESCO online Survey. Paris, France: UNESCO Living Heritage Entity. Document available at: https://ich.unesco.org/en/news/livingheritage-experiences-in-the-context-of-the-covid-19-pandemic-13261

Publisher's Note Springer Nature remains neutral with regard to jurisdictional claims in published maps and institutional affiliations. 